\title{
Investigating peat deposits with ground- penetrating radar - a case study of drained bogs in Western Siberia, Russia
}

\author{
Anna Sinyutkina ${ }^{1, *}$ \\ ${ }^{1}$ Siberian Federal Scientific Centre of Agro-Bio Technologies of the Russian Academy of Sciences, \\ Siberian Research Institute of Agriculture and Peat, Russia
}

\begin{abstract}
This paper deals with the assessment of the peat deposit transformation of two drained raised bogs (the Bakchar bog drained for forestry and the Ust-Bakchar bog drained for peat extraction) within the Western Siberian taiga zone. Specifically, the objectives of this study were to: 1) characterise the peat deposits of key sites with the use of groundpenetrating radar (GPR) and manual data; 2) estimate the spatial differentiation of modern peat accumulation rates at the microhabitat level. We used the GPR system "OKO-2" with 250, 700, and $1700 \mathrm{MHz}$ shielded antennas and a displacement sensor. We concluded that the use of this GPR complex allowed the assessment of the total depth of the peat deposit, the depth of the fibric peat layer, and the thickness of the layer formed after drainage. We paid attention to defining the patterns of layers formed at depth after drainage within hummocks or hollow microhabitats. The peat accumulation after drainage was not continual throughout all mire surface, which was most typical for plots of the Ust-Bakchar bog. The modern peat accumulation increased 1.3-2.2 times from hollows to hummocks and it was 2-4 times higher within the Bakchar bog than in the Ust-Bakchar bog.
\end{abstract}

\section{Introduction}

Mires are valuable natural resources which include $12 \%$ of the global carbon stock [1]. As a result of water table drawdown during drainage, mires become a source of carbon dioxide emissions into the atmosphere due to the oxygenation and activation of microbiological processes in peat deposits [2-5]. The drainage effect manifests itself in the transformation of the physical properties of peat deposits. Bulk density is the property of peat that reflects the intensity of its transformation. Usually, bulk density is higher within drained bogs and it significantly increases in layers formed during periods of drainage. For example, in pine bogs in Finland, bulk density was significantly higher in sites drained for forestry $(0.07-0.18 \mathrm{~g} / \mathrm{cm} 3)$ than in pristine sites $\left(0.036-0.133 \mathrm{~g} / \mathrm{cm}^{3}\right)$ in the layers at depths of $0-0.8$ $\mathrm{m}[6]$. The previous research conducted within the taiga zone of Western Siberia shows that increase in bulk density of peat is less significant compared with Europe bogs. The bulk density of peat samples from the layer from the first $0-0.9 \mathrm{~m}$ of drained sites was $0.01-0.25$ $\mathrm{g} / \mathrm{cm}^{3}$ and that of pristine sites $0.03-0.18 \mathrm{~g} / \mathrm{cm}^{3}$. However, we have distinguished a layer

${ }^{*}$ Corresponding author: ankalaeva@yandex.ru 
formed during a period of maximum drainage below and above which the bulk density decreased [7]. The identification of this layer made it possible to present an indirect assessment of peat accumulation rates after drainage. The research carried out with classic field and laboratory methods allowed the trend of peat accumulation for particular plots to be assessed, but the peat exhibited significant spatial differentiation both at the regional level, in bogs, and within microhabitats. This may be explained by differences in the conditions of peat formation before drainage, and the distance to ditches and the margin of bog, among others. Thus, the use of only point data may lead to errors and thus, continual data should be obtained for a more accurate areal assessment of the carbon balance. Ground penetrating radar (GPR) surveys are a perspective and useful method to achieve this. GPR can be used to distinguish layers having different bulk densities, degrees of decomposition, and volumetric water contents [8-10]. The use of GPR allows a continuous array of data along the profile line to be obtained with a high spatial resolution of several $\mathrm{cm}$, which could not be achieved with traditional methods of contact studies of peat deposits.

The aim of our study was to assess the transformation of peat deposits in drained raised bogs in Western Siberia with the use of GPR. Specifically, the objectives of this study were to: 1) characterise the peat deposits in key sites with the use of GPR and manual data; 2) estimate the spatial differentiation of modern peat accumulation rates at the microhabitat level.

\section{Objects and methods}

\subsection{Study area}

The objects of this research were two raised bogs within the southern taiga subzone of Western Siberia. The studied territory consists of sandy clay deposits of Lower Quaternary and Middle Quaternary age, occurring in an interfluvial valley, and clay, clay loam, and sand, occurring on a river terrace. The climate is continental, with long and cool winters and short and warm summers. The average annual temperature is about $0{ }^{\circ} \mathrm{C}$. The average annual precipitation is $475-519 \mathrm{~mm}$, with a total annual evaporation of $350 \mathrm{~mm}$ [11]. The percent of mires within the southern taiga subzone is $40 \%$ with predominant bogs and poor fens. The drainage of raised bogs began in the 1960s in the study area, mainly for agricultural and forestry activities, but also for peat extraction, before ceasing in the 1990s. Drainage was carried out on the site via a network of open ditches over a distance of 150-180 m for forestry and $20-60 \mathrm{~m}$ for peat extraction.

The characteristics of the key sites are shown in table 1.

Table 1. Characteristics of the key sites.

\begin{tabular}{|l|c|c|c|c|}
\hline \multicolumn{1}{|c|}{ Key site } & Plot number & Coordinates & $\begin{array}{c}\text { Plant } \\
\text { community }\end{array}$ & $\begin{array}{c}\text { Water table } \\
\text { level (cm) }\end{array}$ \\
\hline \multirow{2}{*}{$\begin{array}{l}\text { Bakchar bog } \\
\text { (BB) }\end{array}$} & BB 1 & $\begin{array}{l}56^{\circ} 53^{\prime} 29^{\prime \prime} \mathrm{N} \\
82^{\circ} 40^{\prime} 47^{\prime \prime} \mathrm{E}\end{array}$ & $\begin{array}{c}\text { pine dwarf-shrub } \\
\text { Sphagnum }\end{array}$ & -26 \\
\cline { 2 - 5 } & BB 2 & $\begin{array}{l}56^{\circ} 53^{\prime} 48^{\prime \prime} \mathrm{N} \\
82^{\circ} 40^{\prime} 56^{\prime \prime} \mathrm{E}\end{array}$ & $\begin{array}{c}\text { pine dwarf-shrub } \\
\text { Sphagnum }\end{array}$ & -11 \\
\hline \multirow{3}{*}{$\begin{array}{l}\text { Ust-Bakchar } \\
\text { bog (UBB) }\end{array}$} & UBB1 & $\begin{array}{l}57^{\circ} 34^{\prime} 41^{\prime \prime} \mathrm{N} \\
82^{\circ} 16^{\prime} 26^{\prime \prime} \mathrm{E}\end{array}$ & $\begin{array}{c}\text { pine and dwarf- } \\
\text { shrub }\end{array}$ & -42 \\
\cline { 2 - 5 } & $\mathrm{UBB} 2$ & $\begin{array}{l}57^{\circ} 34^{\prime} 33^{\prime \prime} \mathrm{N} \\
82^{\circ} 16^{\prime} 22^{\prime \prime} \mathrm{E}\end{array}$ & $\begin{array}{c}\text { birch, pine, } \\
\text { dwarf-shrub and } \\
\text { Sphagnum }\end{array}$ & -27 \\
\hline
\end{tabular}

The first key site was the Bakchar bog (part of the Great Vasyugan Mire) which is situated within the watershed in the basin of the Chaya river. It covers an area of 2,700 $\mathrm{km}^{2}$, with a 
drained site of $77 \mathrm{~km}^{2}$, situated in the central part of the Bakchar bog. The bog was drained in the 1980s for forestry purpose. The second key site named Ust-Bakchar bog is situated on the left floodplain terrace of the Bakchar river (tributary of Chaya river). The bog was drained for peat extraction, with a total area of $3.5 \mathrm{~km}^{2}$ and a drained area of $1.6 \mathrm{~km}^{2}$ (fig.1).

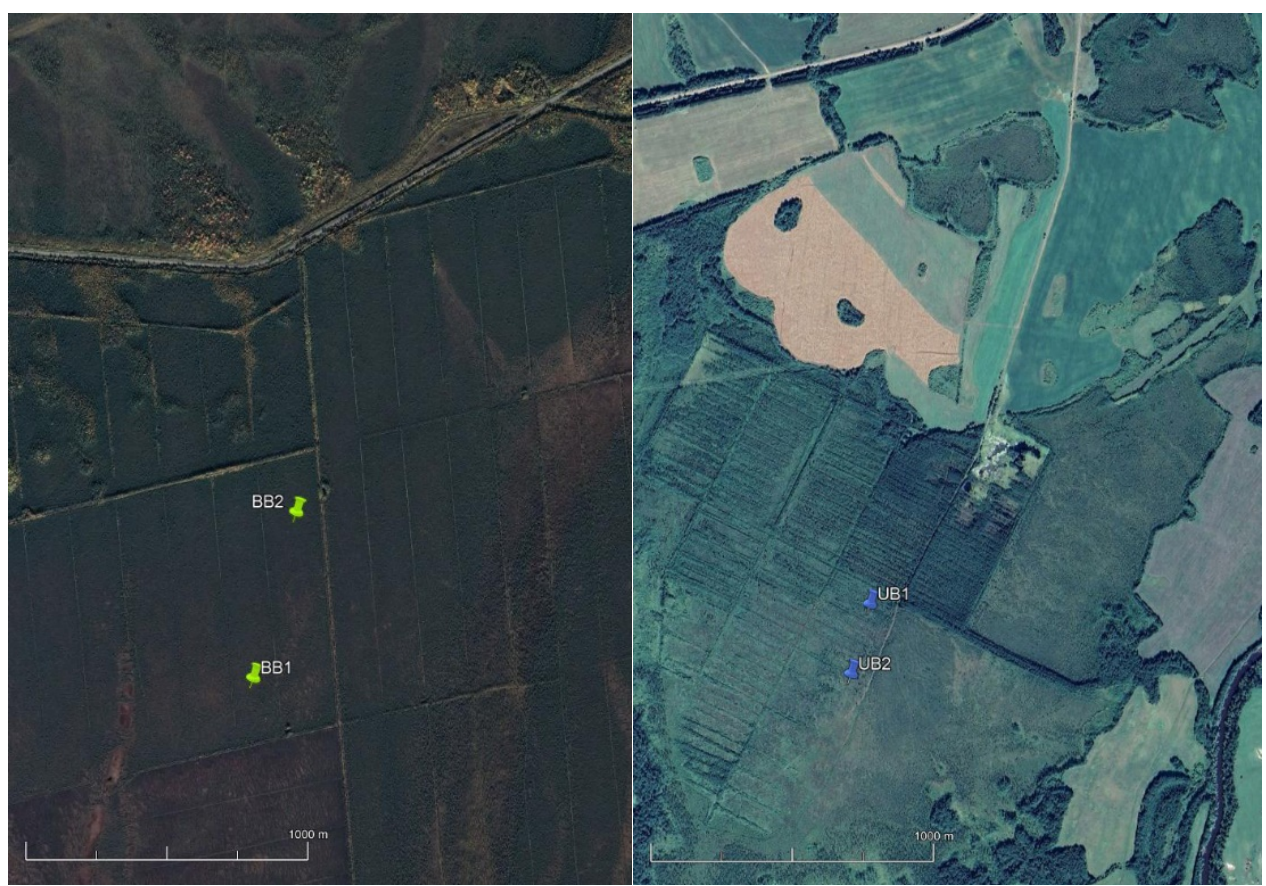

Fig. 1. The key site location (left image - Bakchar bog, right - Ust-Bakchar bog).

\subsection{Methods of field research}

Field research included two main stage:

1. A GPR survey of the peat deposits. We used the GPR system "OKO-2" ("Logical systems", Russia) to conduct a survey of the peat deposits in several steps. The first step included a winter survey of "long" GPR profiles with $250 \mathrm{MHz}$ and $700 \mathrm{MHz}$ shielded antennas and a displacement sensor. The GPR profiles intersected points of manual coring of the peat deposit. The depth of the peat deposit and its stratigraphic layers were determined to target calibration with manual sampling points. The profile length within each key site was determined by the uniformity of the vegetation cover and the features of the drainage network. The second step included a summer survey of four plots with areas of $25 \mathrm{~m}^{2}$ (two per key site) conducted with a GPR system with $1700 \mathrm{MHz}$ shielded antennas in point mode (table 2). The point of the GPR trace corresponded to the point of the total station survey.

Table 2. Parameters of GPR survey.

\begin{tabular}{|c|c|c|c|c|c|}
\hline \multirow{2}{*}{$\begin{array}{l}\text { Antenna } \\
\text { (MHz) }\end{array}$} & \multicolumn{2}{|c|}{$\begin{array}{l}\text { GPR profile } \\
\text { length }(\mathrm{m})\end{array}$} & \multirow{2}{*}{$\begin{array}{c}\text { Timetable, } \\
\text { ns/survey depth } \\
\text { (cm) }\end{array}$} & \multirow{2}{*}{$\begin{array}{l}\text { Spacing of GPR } \\
\text { trace }(\mathbf{c m})\end{array}$} & \multirow{2}{*}{$\begin{array}{l}\text { Depth accuracy } \\
(\mathbf{c m})\end{array}$} \\
\hline & BB & UBB & & & \\
\hline 250 & \multirow{2}{*}{900} & \multirow{2}{*}{350} & $200 / 350$ & 5 & 10 \\
\hline 700 & & & $48 / 80$ & 5 & 5 \\
\hline 1700 & \multicolumn{2}{|c|}{$\begin{array}{l}121 \text { point per } \\
\text { plot }\end{array}$} & $48 / 50$ & 50 & 1 \\
\hline
\end{tabular}


2. Total station survey of the mire surface. The microhabitat differentiation assessment was carried out by a total station survey of plots with a $5 \mathrm{~m}^{2}$ area with a step size of $0.5 \mathrm{~m}$ (121 height points were measured for each plot).

In addition, we determined the mire water level relative to the average surface and made a description of the plant communities within each plot.

\subsection{Data processing}

The GPR data were processed with the GeoScan32 V.2.6 software ("Logical systems", Russia). Data preprocessing included background signal removal by applying an average subtraction, using the gain function to compensate for the signal decay, and zeroing the depth scale in accordance with the peat surface. Layer by layer interpretation included the identification of the reflector depth representing the peat and mineral subsoil interface and the interface between the peat layers with different properties; conversion of the time scale to the depth scale was performed with the use of manual coring data [12].

\section{Results and discussion}

\subsection{Description of peat deposits}

The spatial differentiation of the total peat deposit depth and the depth of fibric Sphagnum peat within the key sites was assessed using the OKO 2 GPR complete with the $250 \mathrm{MHz}$ sounding frequency antenna.

The depth of the peat deposits along the GPR profile within the Bakchar bog increased from 1.9 to $3.6 \mathrm{~m}$ with a mean value $2.5 \mathrm{~m}$. The depth of the fibric peat decreased from 1.7 to $0.8 \mathrm{~m}$ from the first to the second plot with a mean value $1.2 \mathrm{~m}$. The relief of the mineral bottom was undulating without a clearly defined slope in one direction (fig. 2).

According to manual coring data, the depth of the peat deposit was $2.5 \mathrm{~m}$ within BB1 and $2.15 \mathrm{~m}$ within BB2. The peat deposit of BB1, at a depth of $1.75 \mathrm{~m}$, consisted of Sphagnum peat with a decomposition degree of $5-25 \%$, followed by layers of grass-moss, grass, and wood-grass hemic and sapric peat. The degree of decomposition increased to $50 \%$ in the bottom layer of the peat deposit. The thickness of fibric Sphagnum peat in plot BB2 was 1.25 $\mathrm{m}$, with a degree of decomposition of 5-20\%. Wood-grass hemic and sapric peat followed in the lower layers, and the degree of decomposition of the bottom layer was $40 \%$.

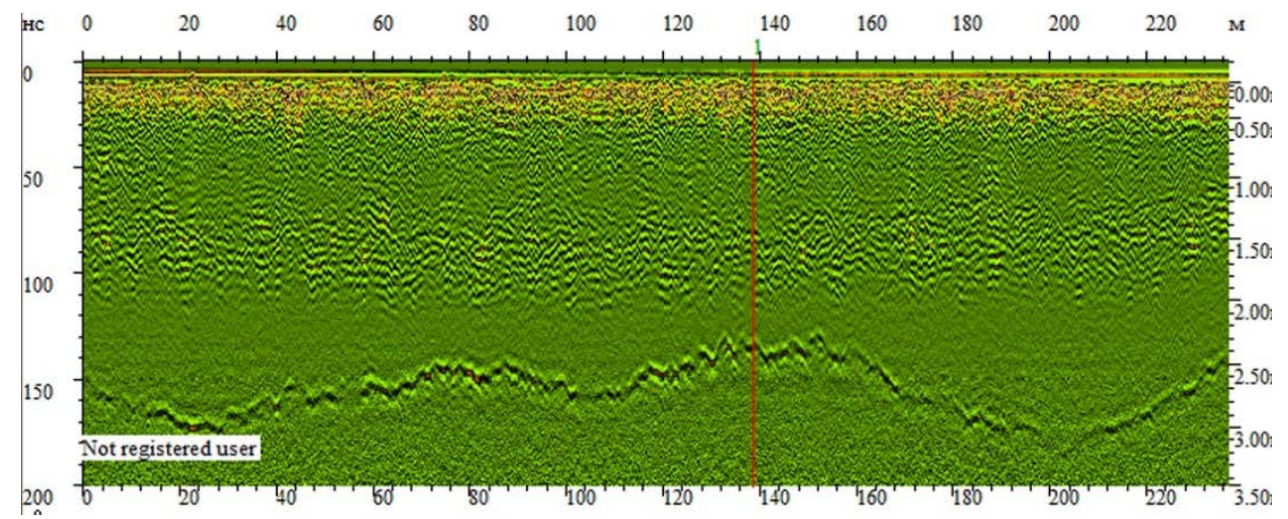

Fig. 2. Fragment of the GPR profile within the Bakchar bog (250 MHz wave frequency) (the black line represents the mineral bottom of the bog and the red vertical line is the point of manual peat sampling). 
The depth of the peat deposit along the GPR profile within the Ust-Bakchar bog increased from 1.7 to $3.5 \mathrm{~m}$ with a mean value of $2.7 \mathrm{~m}$. The mean depth of fibric peat was $1.45 \mathrm{~m}$; it decreased from 1.8 to 1.0 from the UBB1 to the UBB2 plot. The relief of the mineral bottom was flat in the first half of the profile near the UBB1 plot, and it had a depression and rose in the second half of the profile near the UBB2 plot.

According to manual coring data, the UBB1 plot has a $3 \mathrm{~m}$ thick peat deposit. Up to a depth of $1.75 \mathrm{~m}$, it was composed of fibric sphagnum peat with a decomposition rate of 5$15 \%$, followed by layers of grass-moss and wood-grass-moss hemic and sapric peat with a decomposition rate of up to $40 \%$. The depth of the peat deposit on the UBB1 plot was $3 \mathrm{~m}$; up to a depth of $1.75 \mathrm{~m}$, it was composed of fibric sphagnum peat with a decomposition degree of $5-15 \%$, followed by layers of grass-moss and wood-grass-moss peat with a decomposition degree of up to $40 \%$. The depth of the peat deposit at the UB2 site was $1.7 \mathrm{~m}$; up to a depth of $1 \mathrm{~m}$, it was composed of sphagnum fibric peat with a decomposition rate of $5-15 \%$, followed by layers of cotton grass-sphagnum and woody-grass-moss hemic and sapric peat with a decomposition degree of $50 \%$. The mineral bottom of the bog was composed of heavy loam.

Due to the high value of the dielectric permittivity of peat, the determination of pronounced boundaries between the peat layers and between the peat and mineral deposits was possible up to a depth of $3.5 \mathrm{~m}$. This was sufficient to determine the depth of the peat deposit throughout the entire GPR profile at both key sites. We concluded that all key plots that underwent manual coring are typical for the key sites. They had close to average values of depth of both the entire peat deposit and the fibric peat layer with a low degree of decomposition.

The resolution of the $700 \mathrm{MHz}$ antenna did not allow the boundary in the near-surface layer of the peat deposit with a depth of less than $10 \mathrm{~cm}$ to be distinguished, so the use of this set of GPR was effective for studying the peat at a depth of 10-80 cm. It was therefore useful to use this antenna to study the properties of the upper layer of the peat deposit, particularly to determine the boundary between the layers with increasing water contents, which according to a water table level. Within the Ust-Bakchar bog the depth of this layer was similar throughout the profile: the mean value was $17 \mathrm{~cm}$. The depth of the layer decreased from 10 to $20 \mathrm{~cm}$ from BB1 to BB2 with a mean value of $15 \mathrm{~cm}$ within the Bakchar bog. Thus, the use of GPR with 250 and $700 \mathrm{MHz}$ antennas allowed the spatial differentiation of the peat deposit characteristics in the middle scale to be assessed, based the choice of the reprehensive plot of manual sampling.

\subsection{Microhabitat's differentiation of peat accumulation rate}

The surface of pristine pine dwarf-shrub Sphagnum bogs was characterised by the presence of vast moss hummocks and shallow, slightly elongated, or rounded hollows. The amplitude between the highest hummock and deepest low was 30-40 cm and the standard deviation of height was close to 8.5 [13]. There are two ways of transforming the surface depending on the intensity of the drainage. The first way is to increase the height amplitude and standard deviation within bogs with a low intensity of drainage. We observed this first case within both plots of the Bakchar bog, where the amplitude reached $72 \mathrm{~cm}$ and the standard deviation was 12.3. The second way of transforming the surface of the bog is to level the surface through the degradation of mosses covering both lows and hummocks. It was typical for the Ust-Bakchar bog, where the drainage process had more dramatic consequences. We noted a decrease in the height amplitude and standard deviation compared with pristine bogs (up to $32 \mathrm{~cm}$ and 6.8 , respectively). It is obvious that the rate of peat accumulation differed between the habitats, but quantitative estimates have not been made available so far. 
We used GPR with a $1700 \mathrm{MHz}$ antenna to assess the spatial differentiation of peat accumulation at a microhabitat differentiation level. We paid attention to defining the patterns of the layer formed at depth after drainage, which occurred within hummock or hollow microhabitats. The increase in the bulk density of peat was clearly displayed on the oscillograms of the GPR trace by increasing the amplitude of the electromagnetic wave. The resolution of the $1700 \mathrm{MHz}$ antenna allowed us to determine the boundary of the near-surface layer beginning at a depth $2-3 \mathrm{~cm}$ and this was sufficient for our goal. The differences between the key plots and between microhabitats in the layer formed at depth after drainage are presented in table 3 .

Table 3. Microhabitat differentiation of modern peat accumulation.

\begin{tabular}{|c|c|c|c|c|}
\hline \multirow{2}{*}{ Key plot } & \multicolumn{3}{|c|}{ Depth of high bulk density layer (cm) } & $\begin{array}{c}\text { Ratio of surface } \\
\text { with peat } \\
\text { accumulation }\end{array}$ \\
\cline { 2 - 5 } & Hummocks & Hollows & Mean & 0.86 \\
\hline BB1 & 12 & 7.5 & 10.7 & 0.84 \\
\hline BB2 & 13 & 7.9 & 11.7 & 0.27 \\
\hline UBB1 & 2.8 & 2.1 & 2.5 & 0.64 \\
\hline UBB2 & 7.5 & 3.4 & 5.5 & \\
\hline
\end{tabular}

The peat accumulation rate was 2-4 times higher within the Bakchar bog than in the UstBakchar bog. This result confirms the data of the manual study [7]. In addition to manual peat sampling data, we were able to estimate significant spatial differentiation at a local level. The peat accumulation after drainage was not continual throughout the whole mire surface, which was most typical for plots in the Ust-Bakchar bog (table 3). The peat accumulation increased 1.3-2.2 times from hollows to hummock. The UBB2 plot was characterised by maximum spatial differentiation between microhabitats. The productivity of the moss species and the decomposition rate of moss litter were major drivers of peat accumulation in raised bogs. Typical hummock species can stay moist during dry conditions (by capillary water transport and dense growth), whereas loose growing carpets more often completely dry out [14]. So, the large difference between hummocks and hollows in the UBB2 plot may be explained by the strong drying out of hollows and the degradation of the Sphagnum cover therein, when the hummock continued to remain wet and Sphagnum continued grows. Under wetter conditions and with less drainage, Sphagnum growth was possible both within the hummocks and the hollows, what we observed within plots of Bakchar bog. The UBB1 plot was characterised by more a significant ecosystem transformation as a result of water table drawdown, and peat accumulation was very low or completely absent both within the hummocks and hollows.

\section{Conclusions}

The results of this study allowed us to conclude that:

1) A GPR system with $250 \mathrm{MHz}, 700 \mathrm{MHz}$, and $1700 \mathrm{MHz}$ shielded antennas can be used to assess the total depth of the peat deposit, the depth of the fibric peat layer, and the thickness of the layer formed after drainage.

2) The peat deposit was more uniform between plots within the Bakchar bog despite the greater GPR profile length. The Ust-Bakchar bog, in turn, had a mineral bottom with a more curved relief, as well as a depression and a rise particularly when approaching the UBB2 plot. The differences in the natural conditions before drainage might explain the different drainage effects between both plots despite their similar position within the ditch network.

3) The peat accumulation was characterised by significant differentiation at the local scale on the level of microhabitats. The peat accumulation after drainage was not continual throughout the whole mire surface, and modern peat accumulation was often absent in the 
hollows. So, the efficient use of continual surveys to avoid errors in estimating peat accumulation only by manual sampling at a point.

4) The consequences of drainage were more dramatic within the Ust-Bakchar bog, which had previously been drained for peat extraction. Indeed, modern peat accumulation was absent in about $70 \%$ of the surface of the UBB1 plot.

\section{Acknowledgements}

The research was carried out with financial support from the RSF in the framework of the scientific project No. 19-77-00010.

\section{References}

1. M. Amani, B. Salehi, S. Mahdavi, B. Brisco, ISPRS J. Photogramm Remote Sens. 144, 119-136 (2018)

2. K.L. Bacon, A.J. Baird, A. Blundell, M.-A. Bourgault, P.J. Chapman, G. Dargie, G.P. Dooling, C. Gee, J. Holden, T. Kelly, K.A. McKendrick-Smith, P.J. Morris, A. Noble, S.M. Palmer, A. Quillet, G.T. Swindles, E.J. Watson, D.M. Young, Mires and Peat 19(12), 1-23 (2017)

3. J. Paal, I. Jürjendal, A. Suija, A. Kull, Mires and Peat 18, 1-19 (2016)

4. J. Taminskas, R. Linkevičienè, R. Šimanauskienè, L. Jukna, G. Kibirkštis, M. Tamkevičiūtè, Geomorphology 304, 40-49 (2018)

5. K. Brouns, J.T.A. Verhoeven, M.M. Hefting, Sci. Total Environ. 481, 61-68 (2014)

6. K. Minkkinen, J. Laine, Can. J. For. Res. 28, 178-186 (1998)

7. A.A. Sinyutkina, Geosphere Research 1, 78-87 (2020)

8. R. D. Worsfold, S. K. Parashar, T. Perrot, Can. Geotech. J. 23(2), 142-45 (1986)

9. D. J. Daniels, Ground Penetrating Radar. second ed. (London: The Institution of Electrical Engineers, 2004)

10. B. D. Theimer, D. C. Nobes, B. G. Warner, Geophys. Prosp 42, 179-209 (1994)

11. I.V. Karnatsevich, O.V. Mezentseva, Zh.A. Tusupbekov, G.G. Bikbulatova, Renewable resources of heat and water supply in the West Siberian plain and dynamics of their characteristics (FGOU VPO OmGAU Publ., Omsk, 2007)

12. A.A. Sinyutkina, IOP Conf. Ser.: Earth Environ. Sci. 211(1), 012066 (2018)

13. A.A. Sinyutkina, L.P. Gashkova, A.A. Maloletko, M.G. Magur, Y.A. Kharanzhevskaya, Tomsk State University Journal of Biology 43, 196-223 (2018)

14. U. Gunnarsson, J. Bryol. 27, 269-279 (2005) 